\title{
Attitude and consumption of Bangladeshi professionals toward biotechnological products
}

\author{
Abu Habib Md. Abdullah', Md. Safiul Islam Afrad' ${ }^{1}$, A. K. M. Abdul Hannan Bhuiyan², Md. Enamul Haque \\ and Tofazzal Islam
}

\begin{abstract}
Background: To expand the biotechnology market, the opinions of professionals toward biotechnological products are highly valuable for the industry personnel, government policy-makers, and others for taking appropriate decision. Bangladesh is considered as a highly potential country for marketing biotechnological products. It is indispensable to know the present status and future potentiality of biotechnological products to develop a demand-driven market in Bangladesh. This study aimed to assess attitude and consumption of professionals working in public and private organizations in Bangladesh toward biotechnological products.
\end{abstract}

Methods: The data were collected by simple random sampling model, while structured questionnaire provided by the researchers. Collected data were analysed by using Chi-square and logistic regression tests.

Results: Findings reveal that Bangladeshi professionals have an optimistic viewpoint about biotechnology and its products. However, age and education of the respondents had a significant effect on their attitude towards biotechnological products. The most common biotechnological products used by respondents were genetically modified (GM) soybean oil, antibiotics, skin care cream, stress-resistant hybrid rice and vaccine in Bangladesh. Most of the respondents demonstrated a pessimistic consumption level of biotechnological products that showed a menace toward the progress of biotechnology in Bangladesh. However, none of the socio-demographic characteristics of the respondents had a significant effect on the consumption of biotechnological products, but private-sector respondents had a more sanguine stance to consume biotechnological products compared to public-sector respondents.

Conclusion: The favourable attitude and marginal consumption of professional toward biotechnological products reveal that it is important to expand the application of biotechnology to ensure food and nutritional security of Bangladesh. This study includes a limited number of professionals from public and private sectors who have been involved in biotechnological products in Bangladesh. The findings and suggestions for this study might be useful for food producers, industry and food policy makers involved in biotechnological production in Bangladesh.

Keywords: Attitude, Biotechnological products, Consumption, Genetically modified (GM), Professional

\section{Background}

The scientific revolution in molecular biology over the last three decades has led to swift progress in accepting the genetic modification of a living organism and the

\footnotetext{
*Correspondence: tofazzalislam@yahoo.com

${ }^{3}$ Department of Biotechnology, Bangabandhu Sheikh Mujibur Rahman Agricultural University, Gazipur, Bangladesh

Full list of author information is available at the end of the article
}

ability to develop processes and products useful for food security, nutrition and human health [2]. Since the first production of biotechnological products, it has been seen that these products have attracted the increasing attention of the world and are offered for consumption on the wider scale [30]. In fact, the global areas of biotech crops have increased more than 100 -fold from 1.7 million hectares in 1996 to over 179.7 million hectares in 2015, which continues to grow rapidly [18]. The countries that 
have allotted the largest planting areas to biotech crops are the USA (40.01\%), Brazil (23\%), India (6.28\%), Canada (6.16\%), China (2.4\%), Paraguay (2.05\%) and South Africa (1.66\%) [17]. The trends of introducing new and cultivation of existing biotech crops are increasing dramatically in many developed and developing countries.

There is a huge variation in attitude and consumption of biotechnological products among various nations in the world [3]. The literature shows that the attitude of Americans towards biotechnological products is more positive than those of Canadians and citizens of the European Union [1]. China is still struggling with issues of consumer safety and acceptance, whereas many competing factors are putting pressures on policy makers to decide decision towards continuing of commercializing transgenic crops [15]. Most Korean consumers have been reported to be suspicious of the safety of biotechnological products, with 93\% demanding the labelling of these foods [21]. Although there have been a number of consumers and farmers' studies conducted on knowledge, attitude and behaviour with regard to genetically modified (GM) foods in both developed [7, 19] and developing countries $[6,34]$ in the world, almost no studies have considered the factors that influence both the attitudes and consumption of Bangladeshi professionals.

While other countries are making impressive progress in biotechnology, Bangladesh has also made a successive improvement in this field. Bangladesh approved the first official release of four genetically modified varieties of insect-resistant Bt brinjal in 2013 for seed production and initial commercialization. This year (2017) about 65,000 farmers all over the country cultivated Bt brinjal which improved marketable yield by at least $30 \%$ and reduced the number of insecticide applications by a massive $70-90 \%$ resulting in a net economic benefit of US\$ 1868 per hectare [13]. Inspired by the success of the country's first commercially released biotech cropBt brinjal- Bangladesh is now doing field testing three more crops developed through applications of genetic engineering which are late blight-resistant potato, Bt cotton and golden rice [10]. In the pharmaceutical industry, Bangladesh can ensure substantial saving of money if Bangladesh did not need to import $80 \%$ of the active ingredients and precursors from developed nation [5].

Bangladesh is an agro-economic country with a large population compared to its land area and resources. It is projected to reach country's population at 192.9 million by 2025 and economic growth transforming the lives of millions, and our food demand is expected to be much higher than its current growth of production. Therefore, a growing need to develop stress-tolerant crop varieties to combat climate change induced disasters such as flood, drought and intrusion of salinity where biotechnology can play crucial roles to resolve these pivotal issues. The attitudes and consumption of professional respondents seem pivotal to measure the acceptance level of biotechnological products in various stages, which is beneficial to the businessman, policy maker, etc., who have the desire to invest in this sector. Therefore, it is crucial to create a demand-driven market of biotechnological products in Bangladesh to ensure increasing demand of food and nutritional security. This study tried to focus two concepts: firstly, the attitude of the respondents which reflect the knowledge and belief of respondents toward biotechnological products and secondly, consumption of biotechnological products by the respondents which shows the extent of consuming the biotech products.

\section{Research framework}

Attitude is a predisposition or a tendency to respond positively or negatively toward a certain idea, object, person or situation. Consumption is a decision to make full use of an innovation as the best course of action available found in the unpublished thesis of Roy in 1997. When an individual takes up a new idea as the best course of action of practices, the phenomenon is named as consumption. In order to develop the conceptual model of the dependent and independent variables of this study, the conceptual model of Rosenberg and Hovland is kept in mind [33]. The dependent variables were attitudes and consumption of biotechnological products. The independent variables were professionals' age, education, length of service, knowledge and information source. The dependent variables are directly influenced by the independent variables. Consequently, the attitudes and consumption towards biotechnological products varied with the selected characteristic of the respondents. Therefore, it is a prerequisite to pondering the contributing factors of attitude and consumption towards biotechnological products. The conceptual framework of the study is shown in Fig. 1.

\section{Methods \\ Respondents}

This small-scale research was conducted as a descriptive survey study on the basis of a simple random sampling model, where interviews were held with 90 respondents, who represent the professionals of Bangladesh. This master's-level study conducted between the joint venture of the Department of Agricultural Extension and Rural Development and Department of Biotechnology in BSMRAU. Therefore, the short time frame of the degree and lack of substantial funding influence the study to conduct within small sample number. The research scientists, university teachers and industry personnel of biotechnology, breeding and biological science disciplines are included in the population as they are well known about 


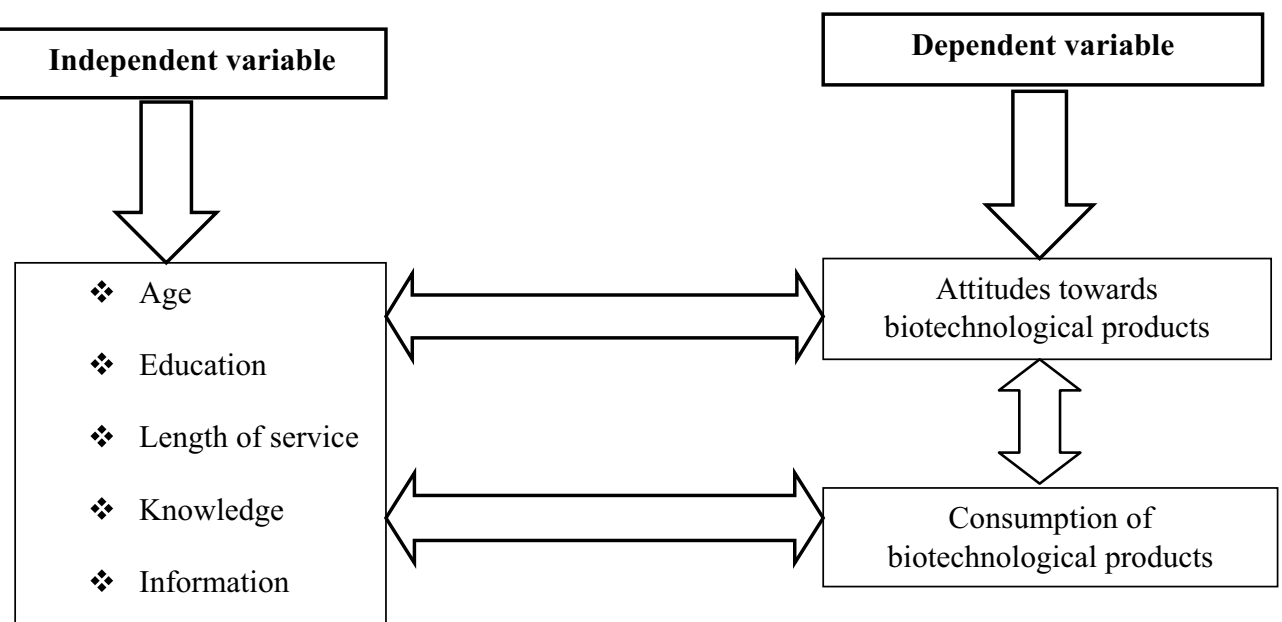

Fig. 1 Theoretical framework: factors influencing the professional attitudes and consumptions of biotechnological products

biotechnological products and they might be unbiased towards biotechnology. Finally, six research scientists, university teachers and industry personnels from the selected 15 public and private organizations, where biotechnology and its related research works are conducting, considered as the sample frame of the study selected by using simple random sampling method from 200 populations. Professionals to be interviewed individually from each institute were randomly selected and face-to-face interviews conducted with this personnel by conforming to unbiased of answers. There is a balanced distribution among the research scientists, university teachers and industry personnel respondents which comprise the whole population.

\section{Questionnaire}

The researchers themselves collected data using a semistructured interview schedule with the respondents. All possible precautions were taken to avert biased opinion and to maintain the reliability of responses. Nevertheless, the biased effect of the interviewer was deducted as far as possible. The entire process of data collection was completed during April to June 2014.

\section{Statistical analysis}

The current study has two categories of variables, viz. dependent and independent variables. The dependent variables were attitude and consumption of the respondents toward biotechnological products, while the independent variables were age, education, length of service, information source and knowledge.

Age of the respondents was measured in terms of actual years based on his/her statement, where a score of one was assigned for each year of his age. The age of the respondents was categorized as young $(<40)$, middle-aged (41-60) and old (> 60). Moreover, education of the respondents was measured by the number of years of formal schooling successfully passed by the respondents where a score of one was assigned to a respondent for each year of schooling. The education of the respondents was categorized as a graduate (16), master's (18) and Ph.D. (21).

Education and length of service were factors that influenced professionalism and code of ethics. Recent findings indicated that practitioners with a high level of education and who had been long in service found accepted professionalism in their practice and also were acceptable to be guided and governed by ethical conduct. Since a majority of them are members of professional associations, it also meant that they accepted ethical practice in the conduct of their work [16]. The length of service of the respondents was measured in terms of actual complete years from his/her date of joining service to the time of interview. The respondents were classified into three categories on the basis of their length of service (years) as short $(<10)$, moderate $(11-20)$ and long $(>20)$.

Use of media by the respondents was measured by the extent of their use of different media of learning biotechnology. Each respondent was asked to mention the degree of contact he/she made with nine selected learning media as daily to weekly, weekly to monthly, monthly to quarterly, quarterly to yearly and not at all, and weights assigned for these five alternative nature of contacts are 4, 3, 2, 1 and 0 , respectively. The selected nine learning media are interpersonal sources (friends, relatives, colleagues and biotech experts), group media (training, group meeting/discussion and workshop/seminar) and mass media (electronic media-radio/television; print media-newspapers/publications; and websites/ the Internet). Based on their score on the use of learning 
media, the respondents are classified into three categories which are a low user $(<12)$, the medium user (13-24) and high user $(>24)$.

The innovation-decision process starts with the knowledge stage. In this step, an individual learns about the existence of biotech products and seeks information about the biotech products. 'What?', 'How?' and 'Why?' are the critical questions in the knowledge phase. During this phase, the individual attempts to determine 'what's the biotech products and why and how it works' [32]. According to Rogers, the questions form three types of knowledge: (1) awareness knowledge, (2) principle knowledge and (3) application/ how-to knowledge.

- Awareness knowledge: Awareness knowledge represents the knowledge of the biotech product existence. This type of knowledge can motivate the individual to learn more about the biotech products and, eventually, to adopt it. Likewise, it may encourage an individual to learn about other two types of knowledge.

- Principle knowledge: This knowledge includes the functioning principles describing how and why the biotech products work. The biotech products can be adopted without this knowledge, but the misuse of the biotech products may cause its discontinuance.

- Application/how-to knowledge: This knowledge contains information about how to use the biotech products correctly. When a professional has biology/ biotechnology backgrounds, but may not use biotechnology in research, which indicates that he/she does not have knowledge of how to use it correctly. So, biotechnology is not used at an expected level, since they need help in how to use the biotechnology effectively in research.

Rogers deliberates that this knowledge is an essential variable in the innovation-decision process. To increase the adoption chance of the biotech products, an individual should have a sufficient level of application knowledge prior to the trial of the biotech products. Therefore, this knowledge becomes more critical for relatively molecular biotech products.

The knowledge scores are computed for each participant to determine the degree of his/her awareness and idea about biotechnological products. Thirty questions are selected in the interview schedule for measuring participant's knowledge, which was categorized into three categories, viz. awareness knowledge, principle knowledge and application knowledge. Respondents were asked to answer those questions and score against each item, which is categorized as four (4) for very well known, three (3) for well known, two (2) for known, one (1) for partially known and zero (0) for unknown. Weight for responses on each 10 questions of each knowledge category is added together to get each participant's score on biotechnological products. Therefore, one's knowledge score on biotechnological product scores could range from 0 to 120 , where ' 0 ' indicates 'no knowledge' and '120' indicates 'very high knowledge.' The same scoring was implemented against each item for understanding the awareness about biotechnological products. So, one's awareness knowledge score on biotech product scores could range from 0 to 40 , where ' 0 ' indicates 'no awareness knowledge' and '40' indicates 'very high awareness knowledge'.

An attitude is an expression of favour or disfavour towards a person, place, thing or event. The weight of respondent's answer gave to the positive judgements of attitude in the 5 points of sub-scale (Likert scale) was coded as 5, 4, 3, 2 and 1, corresponding, respectively, to 'strongly agree,' 'agree,' 'no opinion', 'disagree' and 'strongly disagree', and reverse weights were assigned for the negative judgements. Sequentially, strongly agree and agree are categorized as agree, strongly disagree and disagree are categorized as disagree, and no opinion category remains unchanged in the response of the respondents. Moreover, participant's overall attitude towards biotech products was categorized into four categories by summation of all scores of the questions, which are unfavourable $(<20)$, neutral (21-30), favourable (31-40) and highly favourable $(>40)$. Data show two nominal categories such as agree and disagree, which allows carrying out the Chi-square test compared to regression test. Therefore, Chi-square test was used to determine the attitudes of the respondents towards biotechnological products (Appendix 1).

Biotechnological products are categorized into five types such as agro-based, pharmaceuticals, nutraceuticals, beautyceuticals and other types which were opined by the respondent's personal extent of consumption. Each of the 36 products (agro-based-15, pharmaceuticals-5, nutraceuticals -7 , beautyceuticals -6 and others -3 ) had two choices of responses towards their consumption of biotechnological products which were coded as 1 and 0 corresponding to 'consumed' and 'not consumed. Therefore, the possible score for use of biotech products of the respondents could range from 0 to 36 , while ' $<5$ ' indicates very lower use, ' $6-15$ ' indicates medium use and '> 15 ' indicates the very higher use of biotech products.

Logistic regression is dichotomous; that is, the dependent variable can take the value 1 with a probability of success or the value 0 with a probability of failure. Logistic regression was done to find out the probability of their consumption level of biotechnological products whether consumed or not when to interact with their sociodemographic variables. Collected data were coded for 
processing and analysis. The SPSS computer software program 16.0 version was used to perform the data analysis. Qualitative data were converted into quantitative ones by means of suitable scoring, whenever needed. For describing the particular dependent and independent variables, the respondents were classified into several categories in respect of each variable. Frequency counts and percentages as well as means, standard deviations, rank order, cross-tabulation were used for descriptive data.

\section{Results}

\section{Respondent socio-demographic attributes}

Most of the respondents (59\%) were young-aged with an average of 37.23 years. The respondents mostly hold master's (50\%) and Ph.D. (48\%) degrees (Table 1). The respondents are self-identified as 'university teachers' (34\%), 'research scientist' (33\%) and 'industry personnel' (33\%). Nearly three-quarter (74\%) of them have at least 10 -year professional experience.

\section{Variation in understanding and its application} to biotechnological products among respondents

Findings reveal that $63 \%$ of respondent had good knowledge on biotechnological products having 63\% awareness, $53 \%$ principle and $52 \%$ application knowledge.
Among all research scientists, $41 \%$ had awareness knowledge, while $32 \%$ had basic knowledge and only $27 \%$ applied their knowledge in a productive way on biotechnological products (Fig. 2). However, 40 per cent university teachers had awareness knowledge, $31 \%$ had basic knowledge and only $29 \%$ employed their knowledge on biotechnological production in their practical life. Contrastingly, the reverse picture was seen into industry personnel, whereas $44 \%$ had applied knowledge, $33 \%$ had basic knowledge and merely $23 \%$ had awareness knowledge on biotechnological products.

\section{Attitude of professionals toward biotechnological products}

When asked to describe the attitude toward biotechnological products, respondents gave the diverse opinion (Table 2). The most common specific examples of biotechnological products cited were Bt brinjal which accounted for $90 \%$ of the respondents. A vast majority (83\%) of respondents preferred biotechnology to traditional breeding to develop new varieties. As many as $70 \%$ of the respondents opined gene therapy is the key to overcome hereditary diseases. However, almost 56\% of the respondents showed the identical negative attitude toward genetically modified organism (GMO), its effect

Table 1 Socio-demographic variables. Source: author's calculations

\begin{tabular}{|c|c|c|c|c|c|c|c|c|c|}
\hline Age & $\%$ & Education & $\%$ & Length of service & $\%$ & Information source & $\%$ & Knowledge & $\%$ \\
\hline Young & 59 & Graduate & 2 & Short & 74 & Low & 25 & Low & 31 \\
\hline Middle-aged & 27 & Master's & 50 & Moderate & 16 & Medium & 61 & Moderate & 63 \\
\hline Old & 14 & Ph.D. & 48 & Long & 10 & High & 14 & High & 6 \\
\hline
\end{tabular}

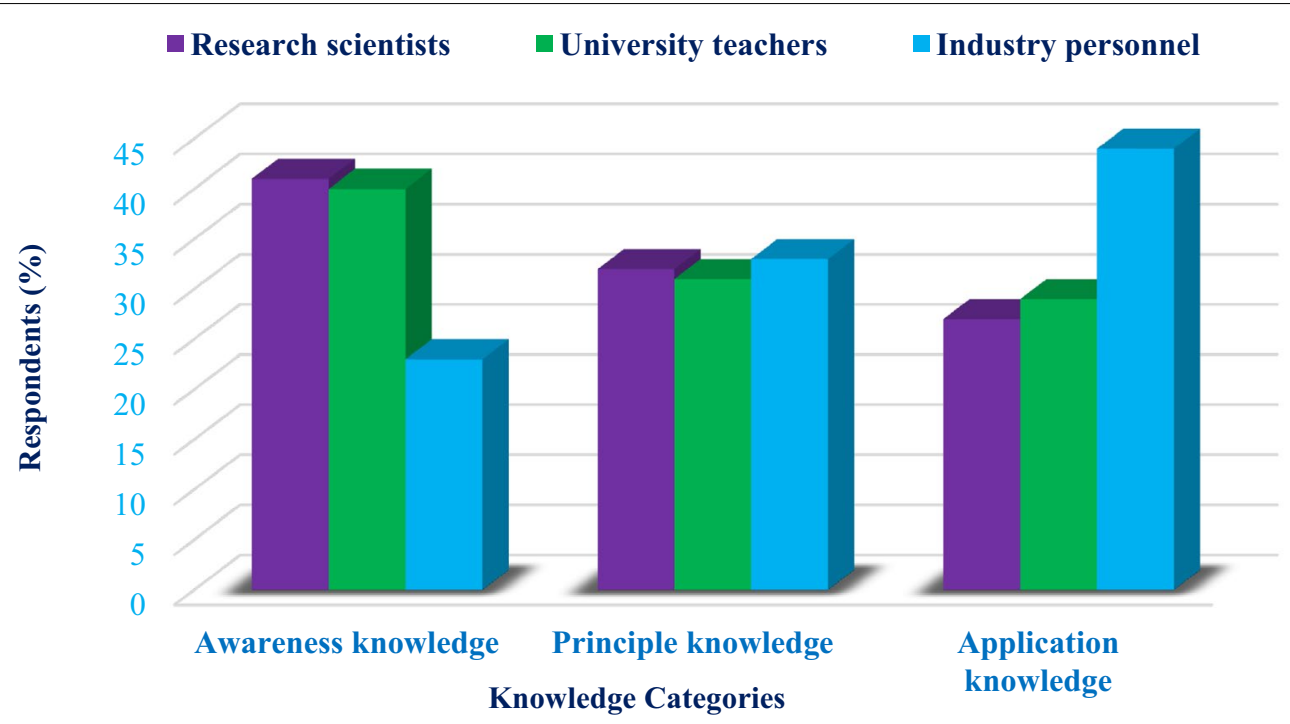

Fig. 2 Knowledge of categorized respondents toward biotechnological products. Source: Author's calculations 
Table 2 Respondent attitudes measuring statement and their responses. Source: Author's calculations

\begin{tabular}{|c|c|c|c|}
\hline \multirow[t]{2}{*}{ Statement } & \multicolumn{3}{|c|}{ Response (\%) } \\
\hline & Agree & Disagree & No opinion \\
\hline In Bangladesh, all soybean oils are genetically modified organism (GMO) & 50 & 32 & 18 \\
\hline Genetically modified (GM) crops will lead to reductions in biodiversity in environment & 56 & 35 & 9 \\
\hline Bt brinjal will be helpful to reduce the attack of brinjal shoot and fruit borer & 90 & 2 & 8 \\
\hline Biotechnological product modification will decrease the natural flavour and taste of food & 57 & 35 & 8 \\
\hline Biotechnology is superior to classical breeding for new variety development & 83 & 7 & 10 \\
\hline The promotion of biotechnological products is due to the greed and self-interest of private companies & 39 & 34 & 27 \\
\hline Gene therapy can be used for the correction of hereditary disease such as diabetics & 70 & 9 & 21 \\
\hline By eating golden rice, one's genes could be modified & 10 & 78 & 12 \\
\hline Transgenic animals in agricultural production systems show relatively inefficient production rate & 11 & 50 & 39 \\
\hline Bt cotton will be helpful to make the cotton useful for human consumption of cotton oil by removing toxicity & 38 & 22 & 40 \\
\hline
\end{tabular}

on biodiversity and biotechnological product effects on natural flavour and taste of food. Usefulness of cotton oil from Bt cotton showed identical response with the profit monger tendency of private company owners, which was expressed by professional respondents. However, a small number of respondents favoured consuming golden rice and high production capacity of transgenic animals.

Nearly three-quarter (71\%) of the respondents revealed a favourable attitude toward biotechnological products as a means of improving the quality of life in Fig. 3. A further distinction is that $81 \%$ of respondents perceived biotechnological products in a positive light having favourable to highly favourable attitude (Fig. 3). Therefore, a great portion of the respondents revealed a favourable attitude toward biotechnological products, which will contribute to developing a demand-driven market of biotechnological products in Bangladesh in near future.

\section{Relationship between socio-demographic variables and attitudes}

Attitude scores were compared on the basis of each selected statements about biotechnological products by participant's socio-demographic variables (age, education, length of service, information sources and knowledge) leading to Table 2 . The critical value of $p$ corresponding to the participant's attitudes toward the biotechnological products (Table 3 ) did not exhibit significant relationship by the length of service, information sources and knowledge ( $p$ 0.415; $p 0.219 ; p 0.208$; > " $p$ $0.05)$. However, there is a significant relationship found

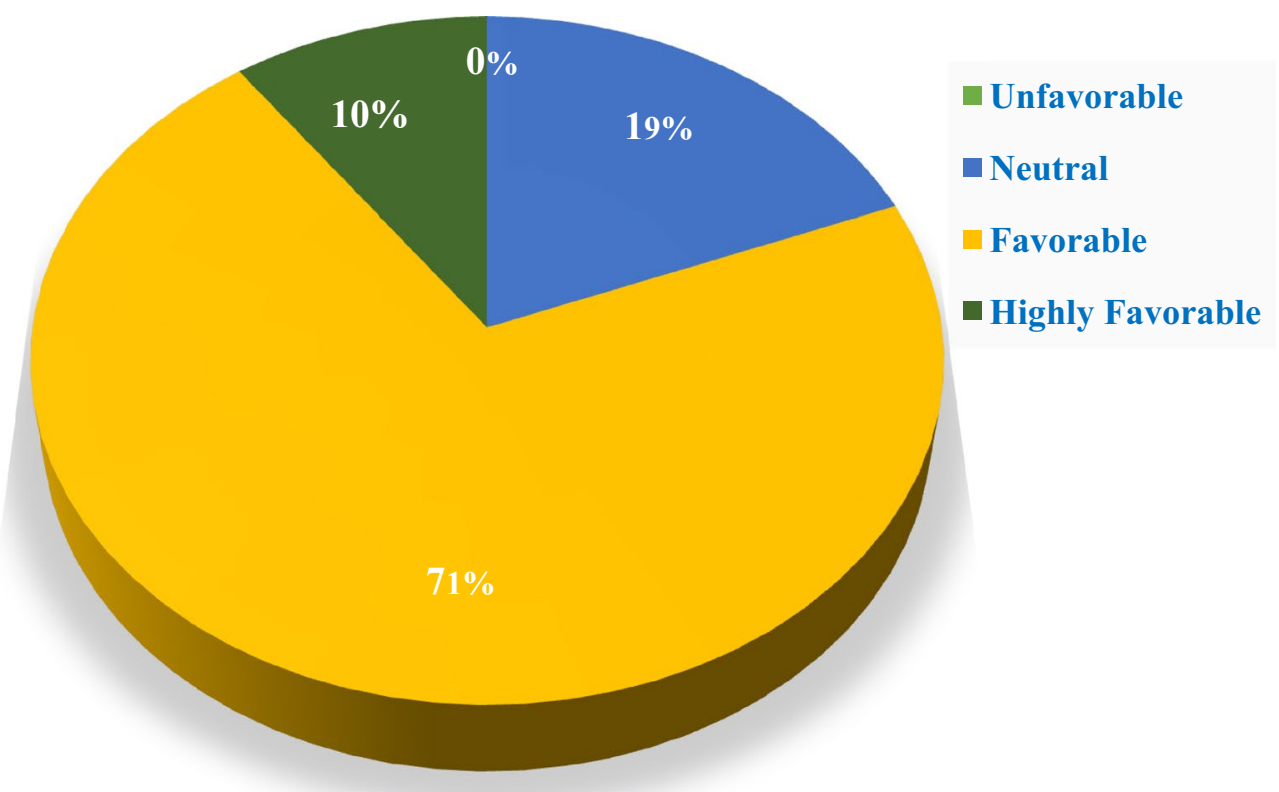

Fig. 3 Respondent overall attitudes toward biotechnological products. Source: Author's calculations 
Table 3 Socio-demographic variables, computed Chi-square value and critical/tabulated Chi-square value of the participant's attitudes. Source: Author's calculations

\begin{tabular}{llll}
\hline & Selected characteristics of respondents & Computed value of ' $\boldsymbol{p}^{\prime}$ & ${\text { Critical value of } \boldsymbol{~} \boldsymbol{p}^{\boldsymbol{\prime} \boldsymbol{*}}}$ \\
\hline Attitudes of the respondents towards biotechnological & Age & $0.004^{*}$ & 0.05 \\
products & Education & $0.029^{*}$ & $0.415^{\mathrm{Ns}}$ \\
& Length of service & $0.219^{\mathrm{Ns}}$ \\
& Information source & $0.208^{\mathrm{Ns}}$ \\
\hline
\end{tabular}

Ns not significant

* $5 \%$ level of significance

with the age and education of the respondents $(p 0.004 ; p$ $0.029 ;<" p 0.05)$.

\section{Consumption of biotechnological products}

Some biotechnological products are introduced or to be introduced in the market of Bangladesh. At most two examples of each category of biotech products are included in the questionnaire to make a significant distinction from other products, yet respondents also expressed their personal consumption of biotechnological products. Therefore, combining both listed products provided in questionnaire and additional products added by the respondents resulted in a complete list of biotech products available in Bangladesh. It revealed that genetically modified soybean oil (16\%), stress-resistant rice (8\%), Bt brinjal (4\%), biofertilizer (3\%), soy sauce $(3 \%)$, soy meat $(2 \%)$, Bt cotton (1\%), virus-resistant potato $(0.5 \%)$, biopesticide (1\%), delayed ripening tomato (3\%), strawberry (2\%), virus-resistant papaya (1\%), orchid flower $(0.5 \%)$, yogurt $(0.5 \%)$, soy protein $(2 \%)$, insulin (2\%), vaccine $(5 \%)$, antibiotics (13\%), anti-cancer drugs (1\%), novel drugs and therapy (0.5\%), breakfast cereal (4\%), soup (4\%), energetic beverage (2\%), energetic capsule $(0.5 \%)$, vitamins $(0.5 \%)$, dietary supplements tablet (1\%), probiotics $(0.5 \%)$, skin care cream $(9 \%)$, anti-ageing cream (1\%), bio facial product (2\%), skin protected face wash (1\%), sunscreen (1\%), body lotion (2\%), biofuel (1\%), leather product $(1 \%)$ and biodegradable plastic $(0.5 \%)$ were used by respondents.

Results also indicate that most of the respondent's used agro-based products, which made up $48.5 \%$, while uprising three (pharmaceuticals, nutraceuticals and beautyceuticals) combined $49 \%$ of total consumption of biotechnological products. The remaining $2.5 \%$ enclosed by other products. Surprisingly, as many as $81.5 \%$ of biotech products are consumable, whereas only $18.5 \%$ of products are used for aesthetic and other purposes. However, as many as $94 \%$ of respondents consume less biotechnological products. Among all biotechnological products found in this study, genetically modified soybean oil is highly consumed by respondents, which was
$16 \%$ of total products used, followed by antibiotics (13\%), skin care cream (9\%), stress-resistant rice $(8 \%)$ and vaccine (5\%) (Fig. 4).

\section{Relationship between socio-demographic variables and consumption levels}

The two-tailed $p$ values of the variables such as age, education, length of service, knowledge and information source are higher than the critical value of $p(p 0.253 ; p$ 0.953; $p$ 0.908; $p$ 0.444; $p 0.305>* 0.05)$ indicates that the null hypothesis could not be rejected (Table 4).

\section{Comparison between public- and private-sector respondents toward biotechnological products}

Two categories of respondents ponder in this research to bring a point of comparison, which are public-sector respondents and private-sector respondents. Publicsector versus private-sector participant's knowledge and attitude seem to be almost identical, i.e. 53 and $51 \%$ versus 47 and 49\% (Fig. 5). However, private-sector respondents are a high user of information source (55\%) and had doubled consumption (68\%) of biotechnological products compared to their counterparts.

\section{Discussion}

Biotechnology especially genetically modified (GM) organism is considered as one of the cutting-edge technologies for achieving food and nutritional security of Bangladesh. One GM food crop, Bt brinjal, is well accepted by both farmers and consumers. In year 2017, more than 65,000 growers cultivated it all over the country. Other GM food crops such as golden rice, late blight-resistant potato and Bt cotton are now at the final stage of field trials. This study for the first time assessed the attitude and consumption of professionals in Bangladesh toward biotechnological products. It is revealed that Bangladeshi professionals have an optimistic outlook about biotechnology and its products. However, age and education of the respondents significantly influenced their attitude toward biotechnological products. Although perception, attitude and acceptance 


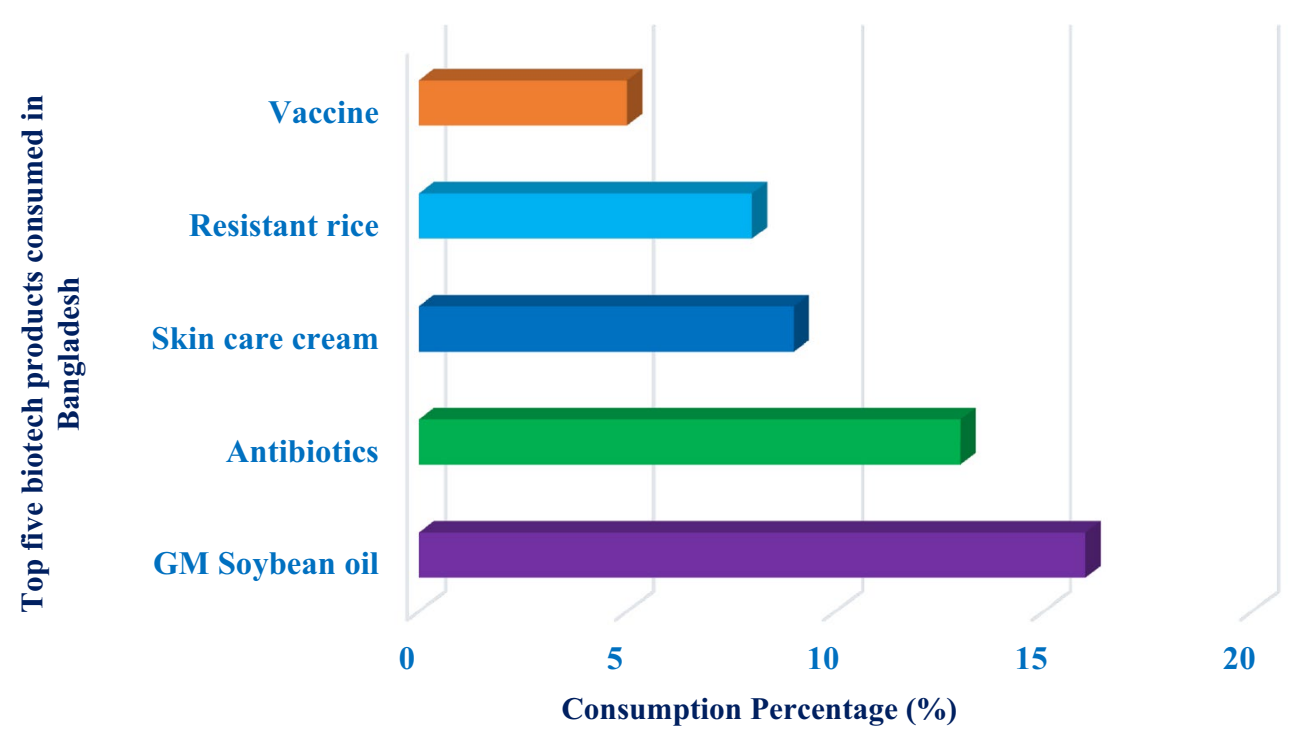

Fig. 4 Major biotechnological products in Bangladesh. Source: Author's calculations

Table 4 Socio-demographic variables, regression coefficient and a significant level of the respondents' consumption. Source: Author's calculations

\begin{tabular}{lcll}
\hline Variables & $\begin{array}{l}\text { Regression } \\
\text { coefficient } \\
(\boldsymbol{B})\end{array}$ & $\begin{array}{l}\text { Exponentiation } \\
\text { of } \boldsymbol{B}\end{array}$ & Significance \\
\hline Age & -0.657 & 0.518 & $0.253^{\mathrm{Ns}}$ \\
Age (1) & -1.941 & 0.144 & 0.365 \\
Age (2) & & & 0.097 \\
Education & 18.773 & 1.423 & $0.953^{\mathrm{Ns}}$ \\
Education (1) & 0.211 & 1.235 & 0.999 \\
Education (2) & & & 0.757 \\
Length of service & 0.284 & 1.329 & $0.908^{\mathrm{Ns}}$ \\
Length of service (1) & 0.570 & 1.768 & 0.785 \\
Length of service (2) & & & 0.667 \\
Knowledge & -0.089 & 0.915 & $0.444^{\mathrm{Ns}}$ \\
Knowledge (1) & -0.853 & 0.426 & 0.950 \\
Knowledge (2) & & & 0.514 \\
Information source & & & $0.305^{\mathrm{Ns}}$ \\
Information source (1) & 1.255 & 3.509 & 0.238 \\
Information source (2) & -0.020 & 0.980 & 0.980 \\
Constant & 1.750 & 5.756 & 0.399 \\
\hline
\end{tabular}

Ns not significant

of consumers and professionals toward biotechnological products have been investigated in many countries [1, $3,11,15]$, this study for the first time assessed and compared the attitude and consumption of professionals from both public and private sectors towards biotechnological products in a developing country, Bangladesh.

One of the interesting findings of this study is that a large majority of the respondents $(86 \%)$ were young- to

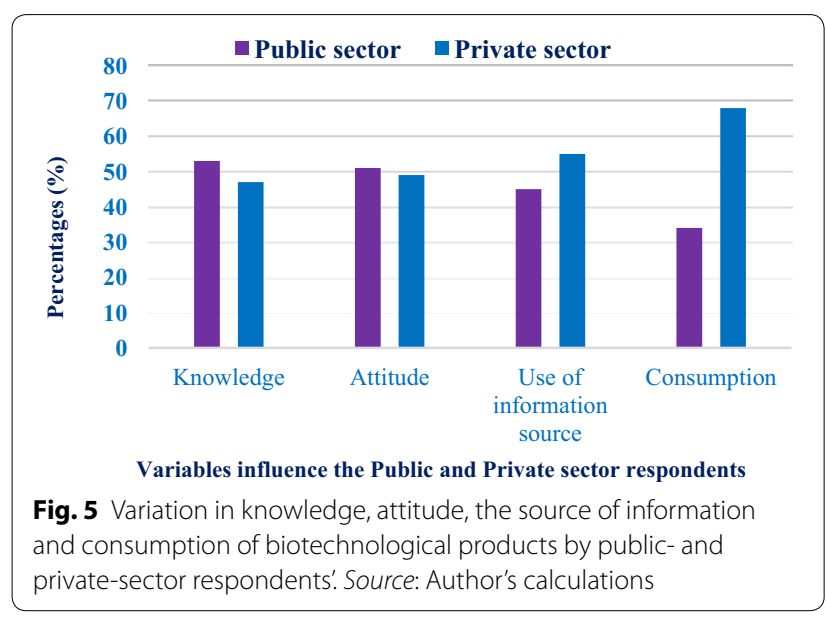

middle-aged categories (Table 1). Almost similar results were found in a study for the Greek consumers [4]. The young- and middle-aged people are more interested in participating in a learning context compared to the oldage people. In current study, majority of the respondents (98\%) had master's to the Ph.D. levels of education. The highly educated Greek consumers were also found to be more aware of the GM products compared to the less educated consumers [4]. Our findings revealed that a great majority of the respondents (90\%) had moderate to a long length of service experience. As biotechnology is a fast moving area, the regular training to young job holders involved in the development of biotech products may be needed for improvement of their professionalism [16].

Media has an important role in informing the people about biotechnology and its products [28]. Nearly 
three-fifths of the respondents moderately used various information sources to gather knowledge on biotechnological products (Table 1). In current study, two-fifths of the respondents used mass media (television, radio, newspaper, research publication and the Internet), which is followed by interpersonal sources (32\%) and group media (31\%), respectively. Similar results were found in sever earlier studies on genetically modified (GM) crops in other countries $[8,40]$.

Timely diffusion of knowledge is necessary to develop an informed society about biotechnological products [22]. To understand the level of the knowledge of the Bangladeshi professionals on biotechnological products, they were asked a series of questions under three categories, viz. awareness knowledge, principle knowledge and application knowledge. Our results indicate that around 63\% of respondents had good knowledge on biotechnological products. Almost similar results were found in American consumers [36], but contrasting results were obtained in a study conducted in south-west Iran [11] and New Jersey [38]. Our results demonstrated that almost $41 \%$ of the research scientists are highly aware of the biotech products, whereas $32 \%$ of them knew the principle information on biotech products, and merely $27 \%$ of them applied their acquired knowledge in their research fields, which is not up to the expected level (Fig. 2). But a strong willingness to involve with biotech product development process was observed in the professionals in China [41]. A significant relationship between knowledge and attitudes has been found in several earlier studies [37,39].

Acquiring knowledge by professionals and their application are critical for biotechnological development of a nation. In present study, around $40 \%$ of the university teachers were aware of the biotech products, while $31 \%$ had known working procedure of those products and a considerable $29 \%$ applied their knowledge in development of biotech products (Fig. 2). Almost similar phenomenon of awareness of knowledge and their implications were found in Slovenian teachers towards GMO [31]. Industry personnel in Bangladesh was highly involved (44\%) in biotech product development although they were not highly aware (23\%) about the biotech products. However, a reverse picture was observed in the industries in Malaysia [29]. In many cases, the research scientists have good knowledge on biotechnological products [14], but their application of knowledge in practical life was not always up to the expected level (Fig. 2).

Biotechnology is strongly influenced by the public attitude [27]. In current study, most of the respondents opined that Bt brinjal could be helpful to reduce the attack of brinjal shoot and fruit borer (Table 2). It implies that Bangladeshi professionals understand the effectiveness and consequences of Bt brinjal and they consider that it is beneficial for the production of brinjal in Bangladesh. Furthermore, many respondents preferred biotechnology as a tool to develop new varieties than traditional breeding. Similar results were found by plant breeders in earlier research [24]. It indicates that respondents understand the principles and mechanisms of biotechnology in the development of crop to ensure food security. In general, Bangladeshi professionals have positive attitude toward hardcore biotechnologies such as golden rice and gene therapy. In an earlier study, it has been found that gene therapy provides the treatment of debilitating, highly penetrant genetic diseases [35].

Transgenic animals in agricultural production systems show relatively inefficient production rate, which is disagreed by respondents of this study. It may be concluded that they are aware of transgenesis and its contribution to the crop production. Additionally, more than $50 \%$ of the respondents showed the negative attitude towards GMO and their consequences on biodiversity, and natural flavour and taste of food. The civil society of Ghana also showed the similar negative attitude towards GMO [20]. In current study, around $71 \%$ of the respondents had a favourable attitude towards biotechnological products (Fig. 3). Similar results were also obtained in China and Australia [22, 23], and contradictory results were found in Spain [25]. It implies that Bangladeshi professionals have good knowledge and perception on biotech products, which lead to their higher attitudes towards biotechnology. Socio-demographic profile of the consumers has been found as a factor which influences the attitude of professional towards biotechnology [4]. Our findings indicate that among all characteristics of the respondents, age and education have a significant positive relationship with their attitude (Table 3). Therefore, respondents of different service length, information sources and knowledge are similar in their pessimistic attitude towards the biotechnological products (Appendix 1). Therefore, the group of respondents with more aged and higher educational levels are more optimistic towards biotech products than younger age and lower educational levels. Almost similar results were found in Swedish consumers [26].

In current study, age, education, length of service, knowledge and information source of the respondents had no significant relationship with their consumption of biotechnological products (Table 4). Therefore, other strong factors may be influenced the consumption of biotech products by Bangladeshi professionals. According to Han and Harrison, consumer consumptions are affected by ethical concerns and the belief that the production of genetically modified foods is harmful to wildlife and the environment [12]. Further research is needed by including highly influencing factors toward the consumption of biotech products to clarify this unresolved issue. 
In Bangladesh, private-sector respondents consumed around $68 \%$ of the biotech products, which is almost double the consumption by the public-sector respondents (Fig. 5). In fact, public-sector respondents had higher knowledge (53\%) and highly favourable attitide (51\%) towards biotech products compared to private-sector respondents. Similar attitudes of public-sector respondents towards biotechnological products have been reported [9]. The public-sector respondents were more knowledgeable and have a strong positive thinking towards biotech products in Bangladesh. They are conducting research on diverse biotechnological products continuously and trying to develop a healthy and ecofriendly product to meet the people demands. Although public-sector respondents have highly optimistic towards biotech products, they do not consume many products than private-sector respondents. However, private-sector respondents are commercially planning to increase the market of the biotech product. Therefore, they have to deal with the ready-made biotech products for advertising and marketing, which arises interest among the personnel to consume more biotech products. Additionally, sometimes private-sector personnel get sample packs of the products for their personal and family use. Therefore, private-sector respondents willingly adopt and use the biotech products due to the availability and less considering the controversial issues. The private-sector respondent had a high user of the information source (55\%) to get latest news of biotech products compared to public-sector respondents (Fig. 5). The private-sector respondents were highly connected to the mass media compared to the public sector which might help themselves to be better up to date about the latest biotech products.

\section{Conclusions}

It is apparent that acreage of cultivation of biotechnological crops is increasing in Bangladesh as well as in the world. Introduction and expansion of biotechnological products in Bangladesh are phenomenal which has been strongly supported by the government. Bangladesh has successfully introduced a GM food crop, Bt brinjal, nationwide without any sensitivity from the consumers, indicating the higher prospects for the expansion of biotechnological products in Bangladesh. The country highly demands new technologies to ensure food and nutritional security of her growing population. However, the positive attitude and negative consumption level of the majority respondents shown in the study toward the biotechnological products seem a challenge in ensuring the safe use of biotechnological products in Bangladesh. This finding indicates the importance of providing right information for creating proper awareness to the population about biotechnological products. The research institutes in Bangladesh need to develop the GM technologies for ensuring food and nutritional security of the nation. To get a greater impact, development of awareness and ethical clarification are also needed for growing a positive attitude by the consumer toward biotech products. Enough extension services, campaign and application of mass media are needed for public awareness to biotech products before releasing them into the market. A further study is needed with the inclusion of a large population of different stakeholders for a precise understanding in existing situation and prospects for biotechnological products in Bangladesh.

\section{Abbreviations \\ ADB: Asian Development Bank; BARl: Bangladesh Agricultural Research Institute; BSMRAU: Bangabandhu Sheikh Mujibur Rahman Agricultural Uni- versity; Bt: Bacillus thuringiensis; DNA: Deoxyribo nucleic acid; GIFT: Genetically Improved Farmed Tilapia; GM: Genetically modified; GMO: Genetically modi- fied organism; ISAAA: International Service for the Acquisition of Agri-biotech Applications; PCR: Polymerase chain reaction; RB: Blight resistant; SPSS: Statisti- cal Package for Social Sciences.}

\section{Authors' contributions}

MSIA was the research major professor. MTI was the research initiator and fund provider of the study. MSIA, MTI, AKMHB and MEH were responsible for the design of the study. MSIA and AHMA designed the statistical analysis. AHMA was responsible for data collection and processing. AHMA, MSIA, MTI, AKMHB and $\mathrm{MEH}$ were involved in writing the manuscript. All authors read and approved the final manuscript.

\section{Author details \\ ${ }^{1}$ Department of Agricultural Extension and Rural Development, Bangabandhu Sheikh Mujibur Rahman Agricultural University, Gazipur, Bangladesh. ${ }^{2}$ Depart- ment of Agricultural Extension and Rural Development, Patuakhali Science and Technology University, Patuakhali, Bangladesh. ${ }^{3}$ Department of Biotech- nology, Bangabandhu Sheikh Mujibur Rahman Agricultural University, Gazipur, Bangladesh.}

\section{Acknowledgements}

We are thankful to Md. Nazmul Hasan for assistance on statistical analysis of the data and Tahsin Islam Sakif of West Virginia University, USA, for linguistic editing.

\section{Competing interests}

The authors declare that they have no competing interests.

\section{Availability of data and materials}

The datasets collected and analysed during the current study are available from the corresponding author on reasonable request.

\section{Consent for publication}

All authors have consent for publication.

\section{Ethics approval and consent to participate}

As this research is a survey of opinions, there were no ethical issues about this study.

\section{Funding}

Special thanks are due to the World Bank for financial assistance for data collection through an HEQEP sub-project CP \# 2071 (to MTI).

\section{Appendix 1}

See Table 5. 


\section{Table 5 Chi-square $\left(x^{2}\right)$ value for attitudes measuring statements towards biotechnological products}

\begin{tabular}{llc}
\hline Sl. no\# & Statements & Chi-square $\left(\boldsymbol{X}^{\mathbf{2}}\right)$ value with $\mathbf{8 8}$ d.f. \\
\hline+1. & In Bangladesh, all soybean oils are GM (from herbicide-resistant soybean plant) & $7.44^{*}$ \\
-2. & GM crops will lead to reductions in biodiversity in environment & $40.33^{*}$ \\
+3. & Bt brinjal will be helpful to reduce the attack of brinjal shoot and fruit borer & $88.59^{*}$ \\
-4. & Biotech product modification will decrease the natural flavour and taste of food & $44.33^{*}$ \\
+5. & Biotechnology is superior to classical breeding for new variety development & $37.56^{*}$ \\
-6. & The promotion of biotech products is due to the greed and self-interest of private companies & $17.45^{*}$ \\
+7. & Gene therapy can be used for the correction of hereditary disease such as diabetics & $68.79^{*}$ \\
-8. & By eating golden rice, a person's genes could be modified & $69.22^{*}$ \\
-9. & Transgenic animals in agricultural production systems show relatively inefficient production rate & $51.89^{*}$ \\
+10. & Bt cotton will be helpful to make the cotton useful for human consumption of cotton oil by removing & $42.56^{*}$
\end{tabular}

*5\% level of significance

\section{Publisher's Note}

Springer Nature remains neutral with regard to jurisdictional claims in published maps and institutional affiliations.

Received: 11 April 2017 Accepted: 28 December 2017

Published online: 01 February 2018

\section{References}

1. Abdulkadri AO, et al. Public perception of genetic engineering and the choice to purchase genetically modified food in Jamaica. J Food Agric Environ. 2007:5(2):8-12.

2. ADB. Agricultural biotechnology, poverty reduction, and food security: a working paper. Manila: Asian Development Bank; 2001.

3 Amin L, Azad MAK, Gausmian MH, Zulkifli F. Determinants of public attitudes to genetically modified salmon. J PLOS ONE. 2014. https://doi. org/10.1371/journal.pone.0086174.

4 Arvanitoyannis IS, Krystallis A. Consumers' beliefs, attitudes and intentions towards genetically modified foods, based on the 'perceived safety vs. benefits' perspective. Int J Food Sci Technol. 2005;40:343-60. https://doi. org/10.1111/j.1365-2621.2004.00916.x.

5 Azad AA. The cure is here. Forum-A monthly publication of the Daily Star. 2009; 3(10).

6 Chen MF, Li HL. The consumers' attitude towards genetically modified food in Taiwan. J Food Qual Prefer. 2007;18(4):662-74.

7 Frewer L, Lassen J, Kettlitz B, Scholderer J, Beekman V, Bernal KG. Societal aspects of genetically modified foods. J Food Chem Toxicol. 2004:42(1):1181-93.

8 Fritz S, Husmann D, Wingenbach G, Rutherford T, Egger $V$, Wadhwa P. Awareness and acceptance of biotechnology issues among youth, undergraduates, and adults. J AgBioForum. 2003;6(4):178-84.

9 Gamble J, Kassardjian E. The use of selected community groups to elicit and understand the values underlying attitudes towards biotechnology. J Public Underst Sci. 2008;17(2):245-59. https://doi. org/10.1177/0963662506065332.

10 Genetic Literacy Project. Golden Rice could be released commercially in Bangladesh as early as 2018. 2016. Available at: https://www.geneticliteracyproject.org/2016/05/13/bangladesh-field-testing-three-gmo-cropspotato-cotton-rice/. Accessed 13 May 2016.

11 Ghasemi S, Karami E, Azadi H. Knowledge, attitudes and behavioral intentions of agricultural professionals towards genetically modified (GM) foods: a case study in Southwest Iran. J Sci Eng. Ethics. 2013;19(3):12011227. https://doi.org/10.1007/s1 1948-012-9383-6, ISSN 1353-3452.

$12 \mathrm{Han} \mathrm{JH}$, Harrison RW. Factors influencing urban consumers' acceptance of genetically modified foods. Rev Agric Econ. 2016;29(4):700-19. https:// doi.org/10.1111/j.1467-9353.2007.00382.x.
13 Hossain MA. Bangladeshi Bt brinjal farmer speaks out in GMO controversy. Cornell Alliance Sci. 2016. Available at: http://allianceforscience. cornell.edu/blog/bangladeshi-bt-brinjal-farmer-speaks-out-gmo-controversy. Accessed 12 July 2016.

14 Hossain F, Onyango B, Schilling B, Hallman W, Adelaja A. Product attributes, consumer benefits and public approval of genetically modified foods. J Consum Stud. 2003;27(5):353-65.

15 Huang J, Rozelle S, Pray C, Wang Q. Plant biotechnology in China. J Sci New Ser. 2002;295(5555):674-677. Available at: http://www.jstor.org/ stable/3075699. Accessed 08 Jan 2009.

16 Idid SA, Arandas MF. Professional values, ethics, and professionalism of public relations practitioners. J Komun Malays J Commun. 2016;32(1):287-311. Available at: http://www.ukm.my/jkom/journal/ pdf_files/2016/V32_1_14.pdf.

17 International Service for the Acquisition of Agri-biotech Applications (ISAAA). Brief executive summary on global status of commercialized biotech/GM crops. 2013. Available at: http://www.isaaa.org/resources/ publications/briefs/46/executivesummary/default.asp Accessed 25 Mar 2014.

18 International Service for the Acquisition of Agri-biotech Applications (ISAAA). Global adoption and approval of biotech crops in 2014. 2015. Available at: http://www.isaaa.org/resources/videos/globalstatusreport2014/default.asp.

19 James J. Consumer knowledge, and acceptance of agricultural biotechnology vary. J Calif Agric. 2004;58(2):99-105.

20 Kangmennaanga J, Oseia L, Armaha FA, Luginaaha I. Genetically modified organisms and the age of (Un) reason? A critical examination of the rhetoric in the GMO public policy debates in Ghana. Futures. 2016;83:3749. https://doi.org/10.1016/j.futures.2016.03.002.

$21 \mathrm{Kim} \mathrm{M}, \mathrm{Kim} \mathrm{H}$. Consumer attitudes, and acceptance of genetically modified organisms in Korea. Int J Consum Stud. 2003;27:3.

22 Lieshout EV, Dawson V. Knowledge of, and attitudes towards healthrelated biotechnology applications amongst Australian year 10 high school students. J Biol Educ. 2016;50(3):329-44. https://doi.org/10.1080/0 0219266.2015 .1117511$.

23 Li Q, Kurtis KR, McCluskey JJ, Wahl TI. Consumer attitudes towards genetically modified foods in Beijing, China. J AgBioForum. 2002;5(4):145-52.

24 Lusser M, Parisi1 C, Plan D, Rodríguez-Cerezo E. Deployment of new biotechnologies in plant breeding. Nat Biotechnol. 2012;30(3):231-239. Available at: http://www.ask-force.org/web/Regulation/Lusser-Deployment-New-Biotech-Breeding-2012.pdf.

25 Lujan JL, Todt O. Perceptions, attitudes, and ethical valuations: the ambivalence of the public image of biotechnology in Spain. J Public Underst Sci. 2000;9(4):383-92. https://doi.org/10.1088/0963-6625/9/4/303.

26 Magnusson MK, Hursti UKK. Consumer attitudes towards genetically modified foods. J Appet. 2002;39(1):9-24. https://doi.org/10.1006/ appe.2002.0486. 
27 Malyska A, Bolla R, Twardowski T. The role of public opinion in shaping trajectories of agricultural biotechnology. Trends Biotechnol. 2016;34(8):604-5. https://doi.org/10.1016/j.tibtech.2016.03.005.

28 Marques MD, Critchley CR, Walshe J. Attitudes to genetically modified food over time: how trust in organizations and the media cycle predict support. J Public Underst Sci. 2014. https://doi. org/10.1177/0963662514542372.

29 Nordin NH, Noor MNM, Abdullah A, Awal A. A conceptual framework on prioritization factors towards biotechnology inventions commercialization: Malaysia biotechnology industry. J Sci Res Dev. 2016:3(5):125-134. ISSN 1115-7569. Available at: http://jsrad.org/wp-content/2016/Issue\%20 5,\%202016/20j.pdf.

30 Oguz O. Attitudes of consumers towards the effects of genetically modified organisms (Biotechnological products): the example of Turkey. J Food Agric Environ. 2009;7(3\&4):159-65.

31 Orgo AS, Dolinsek AJ. Knowledge of, attitudes towards, and acceptance of Genetically Modified organisms among prospective teachers of biology, home economics, and grade school in Slovenia. J Biochem Mol Biol Educ. 2010;38(3):141-50.

32 Rogers EM. Diffusion of innovations. 5th ed. New York: Free Press; 2003. p. 21.

33 Rosenberg M, Hovland $\mathrm{Cl}$. Research on communication and attitude quoted in Triandis, H. C. 1971. Attitude and attitude change. New York: John Wiley Publisher; 1960.
34 Sheikhha MH, Kalantar SM, Vahidi AR, Faghihi M. Public knowledge and perceptions of biotechnology and genetically modified organisms in Iran. J Biotechnol. 2006;4(2):130-6.

35 Sheridan C. Gene therapy finds its niche. Nat Biotechnol. 2011;29(2):121128. Available at: http://www.wissenschaftsdialog.de/624\%20Sheridan\%20GT.pdf.

36 Teisl MF, Garner L, Roe B, Vayda ME. Genetically modified food: What are Mainers thinking? Maine Policy Rev. 2004;13(1):56-67.

37 Tikka PM, Kuitunen MT, Tynys SM. Effects of educational background on students' attitudes, activity levels, and knowledge concerning the environment. J Environ Educ. 2000;31(3):12-9.

38 Vecchione M, Feldmana C, Wunderlich S. Consumer knowledge and attitudes about genetically modified food products and labeling policy. Int J Food Sci Nutr. 2015;66(3):329-35. https://doi.org/10.3109/09637486. 2014.986072

39 Weaver AA. Determinants of environmental attitudes. Int J Sociol. 2002;32(1):77-108.

40 Wheeler S. Factors influencing agricultural professionals'attitudes towards organic agriculture and biotechnology. Australia: University of South Australia. 2005. http://een.anu.edu.au/e05prpap/wheeler.pdf.

41 Zhang X, Huang J, Qiu H, Huang Z. A consumer segmentation study with regards to genetically modified food in urban China. Food Policy. 2010 https://doi.org/10.1016/j.foodpol.2010.04.008.

\section{Submit your next manuscript to BioMed Central and we will help you at every step:}

- We accept pre-submission inquiries

- Our selector tool helps you to find the most relevant journal

- We provide round the clock customer support

- Convenient online submission

- Thorough peer review

- Inclusion in PubMed and all major indexing services

- Maximum visibility for your research

Submit your manuscript at www.biomedcentral.com/submit 